\title{
¿CÓMO SE PERCIBE LA APLICACIÓN DE PROCESOS DE CALIDAD DE LA INGENIERÍA, EN LA ADMINISTRACIÓN PÚBLICA?
}

\author{
Teresa Zamora-Lobato \\ Instituto Tecnológico Superior de Misantla \\ teresa_zamora76@hotmail.com \\ Mario Hernández Vargas \\ UCC Business School Universidad Cristóbal Colón \\ Jesica J Ramos-Hernández \\ UCC Business School Universidad Cristóbal Colón \\ Yodaira Borroto Pentón \\ 4Instituto Tecnológico Superior de Misantla
}

Recepción Artículo: 12 marzo 2021

Admisión Evaluación: 15 marzo 2021

Informe Evaluador 1: 18 marzo 2021

Informe Evaluador 2: 20 marzo 2021

Aprobación Publicación: 22 marzo 2021

\section{RESUMEN}

El objeto de esta investigación son los procesos de calidad aplicados en la Administración Portuaria de Veracruz, misma que es la encargada de proporcionar infraestructura y servicios portuarios, con un modelo logístico eficiente, que favorezca la optimización de los costos en las cadenas de valor de las mercancías, generando mayor rentabilidad para el puerto y sus socios comerciales. Se realizó una investigación entre el personal de mando de la APIVER y el personal externo que labora en el recinto portuario, en el cual se aplicó un cuestionario mediante una aplicación de Google, para darnos cuenta del nivel de conocimiento que cuentan con los procesos de calidad.

Palabras clave: administración pública; procesos de calidad; gobierno JEL: H83, L15, G3

\section{ABSTRACT}

Engineering quality process in public administration: How is perceived? This research focuses on the quality processes applied in the Port Administration of Veracruz (APIVER). Responsible for providing infrastructure and port services with an efficient logistics model that favors the optimization of costs in the goods value chains, which generating greater profitability for the port and its business partners. We carried out a study among the APIVER command staff and the external staff working in the port area. To do this, was applied the questionnaire through a Google app, in order to find out the level of knowledge they have regarding the quality processes.

Keywords: public administration; quality processes; government 


\section{¿CÓMO SE PERCIBE LA APLICACIÓN DE PROCESOS DE CALIDAD DE LA INGENIERÍA, EN LA ADMINISTRACIÓN PÚBLICA?}

\section{INTRODUCTION}

Quality processes originated in private companies, starting in Japan and later adopted in several countries due to their improvement in related processes. Furthermore, in the scope of their public administration processes, several governments consider quality as a fundamental part of their structure and some of them have implemented specialized areas in charge of supervising the daily compliance of quality key points. When the internal processes in the companies are reviewed, we may know the actions of each person involved and how they are considered, as if they were part of a machinery. Remember that each person is as important as the team. Because of this, there is competitiveness among private companies, which seek to obtain the liking of customers.

However, in public administration the processes not always are supervised by the quality area, which could cause them not to improve the way they provide services. Therefore, this study seeks to demonstrate how government and private companies are providing services, hence it is necessary to identify whether quality processes in public administration are suitable to be applied.

Our study case is the Integrated Port Administration of Veracruz, S.A. DE C.V. (APIVER for its acronyms), where a quality process, has been implemented. Unfortunately, it is not an internationally recognized regulation; it is a hybrid model that includes key points adapted to the company. This model has taken as reference several existing quality models, and the classical authors on total quality, such as Deming, Crosby, Juran and Ishikawa, are also considered as theoretical bases. Under this premise, different theoretical and empirical currents involved in the public administration quality process will be analyzed in order to measure the possible influence of the quality process implemented by the company in the final product.

\section{DESCRIPTION OF THE PROBLEM}

About the problematic that we discusses, the object of this research focuses on a study about the application of quality process implemented by public administration; therefore, it is necessary describing important aspects that have given form and basis to the area of quality processes. In relationship to the quality models we may say that offer two key points in their development: on one hand, the process and on the other one, the results. In regard to applicability, we cannot talk about one of these concepts and exclude the other one, because both of them are intertwined in order to create a binomial that supports and provides the basis of quality processes. So, if the process is optimal, efficient and attached to the established standards, the effect or consequence will necessarily be the reflection of the first one, that is, the result will be the tangible product of doing things properly.

About this, [2] has pointed out that quality models originally present in private companies, are a clear example of where should public administration in Mexico head to. Also, it is important to mention that the regulation UNE-EN ISO 9000:2000 defines a process as the "set of activities mutually related or that interact, to transform entry elements in results" (Op. cit, 2). As mentioned previously, the quality process started in the private company, where businessman concerned about competition in their industry were forced to provide the best service to the client. The users have the choice of picking between two or more companies of the same trade, a situation that does not take place in public administration provided by the government, which is the organization in charge of providing this public service.

When the user comes to buy a product or service, the attention given by the store employee is not random, it follows a quality manual that was previously thoroughly studied to satisfy the customer's needs. Even if it is true that there is no law on the quality process in companies or public administration, it is a fact that they will help improve the services they provided.

The current meaning of quality is an important component of neo-management reforms applied to public administration, identifiable and far-reaching in application, although it is not synonymous with success. Similar to the other elements of the new public management, it is a tool adopted in private organizations and applied by international associations and agencies, which in this way have had a certain impact on the management of affairs in the nation state. 
Regarding quality in public administration, [20] mentions that there are two lines of development: one refers to the improvement of perception by the consumer-client-citizen and the other one is an internal aspect, the improvement of processes and procedures of the quality management. In the first one, the acting guide that correspond to the service or commitment letters to the citizen and the second one, correspond to the application and use of quality standards like ISO.

To understand a little more about what ISO is, we consider the definition located on its web page: The International Organization for Standardization, known by its abbreviation (ISO) is an organization for the creation of international standards made up by several national standardization organizations1. In the last decades, the international financial agencies such as academic venues and several areas of government management in Mexico s public administration have carried out not only a conceptual modification to the way quality processes are done, but also an explicit pretension of transformations in the design, implementation and evaluation to processes applied to citizen attention.

In the topic of modern public administration, [17] states that development is linked to the advent of society and rule of law in the XVIII century. This fact is typical of living conditions aimed to the differentiation of structures, systems and processes that have their basis in the distinction of private and public. Therefore, public administration is not a stranger to the transformations that reflect the distinction of competition scopes to avoid confusions, hybrids or imprecision contrary to the dynamic of modernization and development of institutional life.

Modern public administration is liked to collective life projects, it is the author, co-author and maker of said projects because its attributions extend to all parts of community life, understood as the life of public spaces. Even though administrative institutions have changed power structures such as the ones of institutional monarchy, liberal governments or contemporary state, they have currently lost an active presence in relation to the favor of public interest, due to the fact that the approaches and thesis of free market have highlighted the relevance of private and not so much the public (0p. Cit 2009).

Additionally, the energies of civil society also impact in the demand of public affairs as not to continue the monopoly of state institutions, in particular the referred to productive activities and services. As previously stated, public administration has a close relationship to the activities of people, such as the use of parks, highways, public hospitals, libraries, museums and all sorts of services lent by the government, whether it is federal, state or city wide. As they are users of services lent by an operator to a user, they most keep quality standards that are supervised by an agency such as the International Organization for Standardization.

Uvalle (2009) [17] keeps pointing out that the new structural conditions -innovation and technological change- of the contemporary society force administrative institutions to be more valued by quality, productivity and re-design schemes, which modifies the pattern followed during the stage of state wellbeing. The culture of quality and productivity are invoked as the referent to carry out a structural and functional transformation of public administration over the basis of privatization, external hiring and concession policies in favor of society s economical agents.

The market becomes a prime example of efficient work, quality practices and innovation processes that allow the decrease of costs, increase productivity and satisfy the users of goods and services. The market is invoked to evaluate the performance of public administration and thus, it is recommended to improve performance and final results. The market is taken so that public administration eliminates failures, mistakes and omissions based in political arrangements, the maximization of bureaucratic benefits, the advantages of administrative positions and the exploitation of budgets for advantage and economic support.

Nowadays, technologies are kept on edge, we must be constantly up to date as not to fall to the precipice, the advances are applied in public administration since technology must be applied for the citizens; for example, a city of 100,000 habitants requires a collection system, interconnected to all the areas where collection is required, all these procedures must be govern by a surveillance agency regarding quality standards so the final user can receive effective attention. Therefore, In accordance with the quality standards implemented by the company APIV- 


\section{¿CÓMO SE PERCIBE LA APLICACIÓN DE PROCESOS DE CALIDAD DE LA INGENIERÍA, EN LA ADMINISTRACIÓN PÚBLICA?}

ER to carry out their work within this sector as part of the company's business, the following is questioned: How do the workers and the end user perceive the quality processes implemented by APIVER?

\section{PERTINENCE OF THE STUDY}

What is the probability that two or more people have the same expectations when deciding what a high-quality public service is and what is not? When measuring quality, it is possible to assume that people consider several and multiple attributes of a certain service or product and assign different weights to each attribute before arriving to a decision. For [12], a person can see mainly the aptitude for the use of the service, while another see how opportune is the service lent. Being realistic, it can be assumed that most individuals use some combinations of these factors to evaluate quality. It is evident that quality is a complex matter; even though product and service quality is hard to evaluate, the evaluation of quality in organizational policy programs is even harder still.

The evaluation of government quality is feasible for the most demanding and the first pilots in the area are beginning now. Though the former is true, this idea originated in Japan s private companies and many companies in different countries have adopted quality verification in their processes but public administration is far from implementing these standards as many people think that, by being processes watched over by laws and regulations which are slow because of bureaucracy, we could imagine that final users, when dealing with a quality process, would perceive that they are being affected in their final result (0p. cit, 12).

During the last decades, [21], mention to the public sector organizations when facing unprecedented challenges. Budget pressures and the increasing demand of financial responsibility, combined with changing public expectations of public sector services require new approaches and solutions. Therefore, public sector organizations seek to adopt new processes, techniques and technologies to increase the efficiency of new processes, reduce costs, increase quality and encourage more responsibility.

Private sector organizations have achieved a proven success of increasing quality and reducing costs by improving efficiency and processing capacity implementing the best practices in several management techniques. Nowadays, public sector organizations are under pressure to achieve the same results. In line with the experiences of private sector, there is considerable evidence to be found in the literature of public sector about the hypothesis that an efficient use of management techniques is the key to a good performance in public services: "management really matters".

If we consider that currently private sector is directly compared with public sector, in this study we can verify and check the final impact of quality in public administration processes, having to propose a certain process model that, by implementing quality, does not increase the time to obtain the final service for the user. It will be convenient for the company under investigation to know which part of the process is failing, if it will be applied like that in order to correct their processes and have a positive impact for their clients.

To talk about quality in public administration processes, we should understand the opinion from authors who throughout history have proposed and studied the keys to reach the goals imposed by "quality". In relationship of this [11] says that Joseph M. Juran, born in 1904 taught the doctrine of Quality Management and contributed to the great Japanese power revolutionizing their thought and their aptitude in the use of products and services globalize the world.

Among his contributions, there are concepts associated to the decrease of non-quality related costs, progressing in quality throughout time and fixing chronic failures related to the lack of quality. Philip B. Crosby, born on 1926, created the concept of client-supplier relationship and the concept of "Zero Defects" in the beginning of the 1970s, contributions that are part of the companies management. The considered that the key to improve quality was changing the mentality of the senior management. If they expected imperfections and flaws, they would have them since their employees would impose similar expectations to their work.

From previously mentioned, empirical evidence that we can obtained in this study, has the purpose of contributing to the studies which have given substance to the state of the art in this subject. The empirical contribution 
that this evidence will provide, will add to the already existing one, it can also serve as support to study other companies in the same context of this study, that is, in the city of Veracruz.

\section{LITERATURA REVIEW}

Since the object of study is focused on quality processes and HOW influence the final product, besides considering that the study takes place in a public administration organization, it is required to note some aspects about this idea. But, how can we understand public administration?. Firstly, it is important to understand the concept of management, about this [4] say that management is presented as an area of human behavior full of complexities and challenges. It constitutes the process of planning, organizing, directing and controlling the use of the resources of the company, organization or any other entity in order to achieve their goals and objectives.

Also, it is important to point out that the professional who uses management as a means of living can work in the more varied levels of an organization: from the hierarchic level of elemental supervision until general management. It can act in several specialties of management such as: production management (of goods and services lent by the organization), financial management, human resources management, market management, even general management. In each level and specialty of management, situations are different. Furthermore, organizations are different; there are no two identical organizations, as there are no two identical people: each has their own goals, industry, senior management and personnel, internal and external problems, market, financial situation, technology, basic resources, ideology and business policy, etc.

Management can be understood as the systematic set of rules that allow getting the maximum efficiency in the ways of structuring a social organism (Perdomo, 2004 cited in [9]. Then it could be said that public management is made by state organization and institutions whose mission is to manage the country s resources. From these definitions, we retake what [18] points out: that the permanent concern and occupation of public management researchers must be analyzing the outcome of several state agencies to establish what is their use and above all, report the results in favor of the citizens.

New management approaches demand this in the context of a society that every time is more informed and demanding. Therefore, it is important to consider the relevance of the evolution of quality management systems and the need of their integration to the organizations processes. In this regard, [1] highlight that international regulations with better reception worldwide are the implementation of quality and environmental management, which are ISO 9000 and ISO 14000.

These series of regulations emerged as a response to the need of improving the quality of products and processes, as well as controlling environmental aspects. These series of regulations have been updated regularly according to protocols established by the normalizing entity and their most recent version was published at the end of 2015. This last version is based in the experience and leadership as central axis of the management system, which facilitates the conception of an organizational culture for the strategic management of quality and environment under its systemic approach.

Nowadays, there are many currents of thought about quality, management processes and good governance. Among the most important authors regarding quality, we can find [16], who refers Dr. W. Edwards Deming, born in 1900 in the United States and who has become the most influential guru in quality management in the United States and Japan, better known for the "Deming cycle", their "Fourteen points" and the "seven mortal diseases". Deming graduated in engineering and physics from the University of Wyoming and Yale, he was influenced by Dr. Shewhart on his philosophical idea for quality in the development of control graphics and PDSA cycle (Shewhart) when working for Western Electric. From 1927 to 1940 he was a pioneer in the successful use of statistics and sampling methods in the Agriculture department of the United States.

During the Second World War, Deming was hired by the War department and the Census office to implement graphics control and sampling methods. After the war, he helped Japanese companies improve quality in their products with his quality principles and orientation as a consultant. It is possible to see that Deming was one of the greatest authors on quality, which is why, [11] makes a reference to W. Edward Deming and among his con- 


\section{¿CÓMO SE PERCIBE LA APLICACIÓN DE PROCESOS DE CALIDAD DE LA INGENIERÍA, EN LA ADMINISTRACIÓN PÚBLICA?}

tributions, and one of the most important is quality management through statistics control and the improvement of quality on products matching the needs of the consumers. In the year 1958, he was the promoter of quality management in Japan; it is curious that over thirty years had to pass for American companies to notice quality management. This later contribution merited the institutionalization of the Deming award as recognition on his work. If we read more on the subject we can find that Japanese companies were the pioneers in the issue of quality, derived from the big contributions of Deming.

In the same idea, [11] mentions the guru Philip B. Crosby, born in 1926, who created the concept of the relationship between provider and the concept of "zero flaws" in the beginning of the 1970s, contributions that are part of the companies as part of their management. He believed that the key to improve quality is to change the mentality of the senior management: if they expected imperfection and flaws they would get them since their employees would impose similar expectations to their job, but if they considered a higher performance and had a good communication with all levels, it was possible to obtain "zero failures".

About Public Administration, [17] mentions that modern public administration has roots defining it as a discipline with its own identity. This is formed in the XVIII century with the coming of civil society and the rule of law, after the political revolutions destroyed the conditions and the relationships that delayed the coming of modern structures that bring a life of competence scope, specialties and roles to fulfill. In the present, public administration suffers changes aiming to the acceleration of events and facts that are the face of a stage in universal history, characterized by the review of postulates and the reaffirmation of classic elements. The classic is lasting, it survives the ages and times without losing its essence and contributions. The classic is the starting point of art, science, discipline or profession that endures with long-lived and secular scope; in this matter, classic is the most solid background to invoke and retrieve what has been and is the development of scientific, humanistic and technological knowledge.

In the case of public administration, classic is based in the diversity of works and authors located in Germany, France, Italy, United States, South America, Mexico and the United Kingdom in the XIX, XX and XXI centuries. The path of public administration has been long and will continue on the roads conditioning its evolution and development.

Public administration has suffered several evolutions during history: if we search and observe its evolution, we will find that it has been adapting to the citizens needs, considering first that public administration are the processes that are used for the attention of a product or service lent to society by the government in turn.

In the last 30 years, institutions have been the subject of questioning that discredit them in the face of efficiency found in companies, which gives rise to postures boosting conceptual and practical systems that highlight more the advantages of private management over public-government. Frequently we believe about that a company working better than a public institution. However, although may be true, currently most institutions are in an evolution process regarding the quality of their procedures.

In relation to the bureaucratic administration development, [17] point out that, civil society is simultaneous, because the market economy and the requirements of social life demand a functional presence of management abilities and skills. Therefore the management processes are evolving according to the users needs, since in a competitive market, it is required to develop schemes that adapt to the demands of clients or users.

Everything in the bureaucracy is routine, standardized and planned in advance, which makes employees get used to working in complete stability and repeating what they do. This provides security about their future in the bureaucracy. Following the regulations and rules imposed by the bureaucracy, the employees become an executor of the routines and procedures.

In the literature review about quality in the processes, it is possible to find ideas about the management of processes: In regard this; [19] refers to a model associated in the private sector, to quality management systems and the concept of client. It is essential for quality and for management process. Management processes has a certain similarity or match to the bureaucratic paradigm of Weber, which was sought to be replaced in the 1990s 
for the New Public Management (NPM), in a fundamental aspect: the formalization of operations in the organization.

In the statements of the NPM, [6] refers to one of the ideas that stand out, and it is precisely the quality of the service, which aims to achieve a change in the management culture by placing concern for the customer first; however, this concept has been debated in highlighting the differences between the public and private sectors. Thus, quality in the public area must be linked to good results, transparent processes, shared responsibilities, productivity, teamwork, and performance improvement and user service.

Currently, the NPM includes processes of continuous improvement, this because we do not know the final idea of quality processes due to always evolving to provide a better service to the user.

On this subject, [8] talk about "continuous improvement in processes", which from 1950 and in several opportunities during the following two decades, Deming used the PHVA cycle as an introduction to all and each training done to senior management in Japanese companies. From there to these days, this cycle (which was developed by Shewhart), has traveled around the world as an undisputed symbol of Continuous Improvement. The regulations NTP- ISO 9000:2001 base their Continuous improvement scheme of the Quality Management System. In figure 1 we can see the Deming cycle.

Figure 1. Taked of García, Quispe and Ráez (2003)

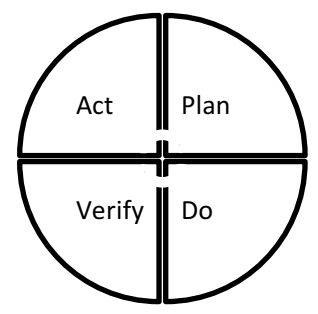

Mohammed (1994) [15] points out that much has been said and written about Total Quality Management (TQM). The interest in TQM as new approach of organizational change and development is even bigger. Observing the development of this models and approaches, we have seen how the new approach in quality and improvement of processes has arisen as a new paradigm in organizational theory and practice. To describe this idea, [15] proposes the next model called "reinventing government through quality management":

Figure 2. Taked of Mohammed (1994)

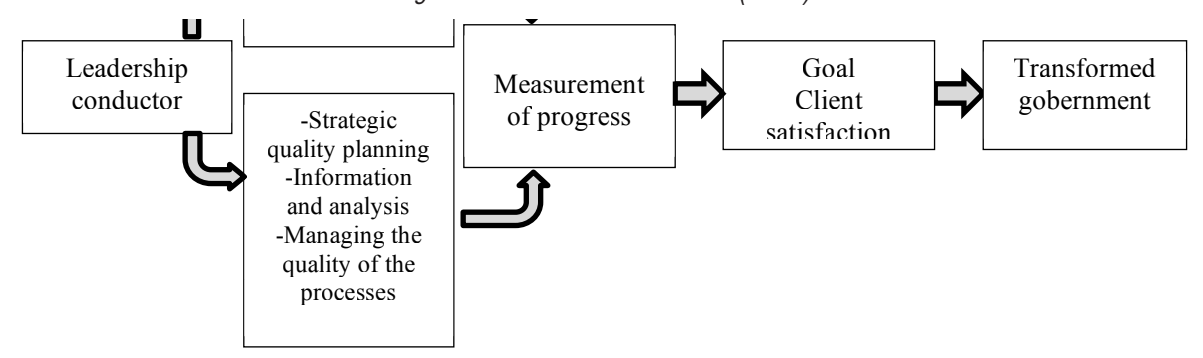




\section{¿CÓMO SE PERCIBE LA APLICACIÓN DE PROCESOS DE CALIDAD DE LA INGENIERÍA, EN LA ADMINISTRACIÓN PÚBLICA?}

In relation to different models of quality management, [7] show several aspects related to the importance and challenges, considered in professional formation, providing indications about where to advance in the path of improvement towards quality. In this context appeared the "white book about education and training: teach and learn. Towards the Europe of knowledge", which has established the guidelines in the matter of training for the European convergence processes in order to create a common space characterized by a high level of competitiveness among the great western powers: United States, Japan and Europe in the new scene of the knowledge society.

In the European continent the model of total quality (TQM) was developed; [7] mention that it was created in 1988 by fourteen companies from Center Europe, leaders in industry and services. Now it has more than 600 members, from small companies to big multinationals, research institutes, business schools and colleges. Influenced by great quality experts, the model pretended to provide a response to the American quality model of the Malcolm Baldridge and the Japanese model of the Deming prize. Its proposal must be situated inside the framework of the quality models developed as new customs of the big powers and multinationals in order to surround the global market. Later, this model evolved since 1999 to the current European model called Excelence (EFQM), aimed to respond to the evolution of certification regulations ISO 9000.

Within the quality processes it is possible to find several activities, such as continuous improvement (Kaizen), [3] explain this relatively new term: its creator, Masaaki Imai took two Japanese ideograms: "Kai" meaning change and "Zen" meaning to improve and thus, Kaizen is "change to improve" or "continuous improvement. The Kaizen has two pillars, which are work teams and industrial engineering, employees to improve productive processes. Their goal is to increase productivity by controlling the manufacturing processes using cycle time's reduction, standardization of quality criteria and operation working methods.

An important subject in the processes is the "organization", which according to [13], is the process of fixing the organization s structure and coordinating its management methods and the use of resources to achieve its goals. Additionally, they mention that the organization is a relatively stable group of people in a system that is structured and evolving, whose coordinated efforts aim to achieve goals in dynamic environments. The organization is a fundamental part of quality processes since without them there would be no order, just a chaos in the company or government, people would divide in opposite directions without achieving an established goal.

On the other hand, the "leading" is the part in charge of coordinating the efforts of personnel who do diverse activities; for [13], leadership is the spine of the organization, since it helps to obtain high levels of productivity using motivation and supervision. Continuing with the administration process, "control" is, according to [13], the process through which administration guarantees if what is happening is what is supposed to happen, otherwise the direction of processes should be adapted or corrected. After the former directives are applied in administrative processes, the organization will attain favorable results, due to the established order and control, thus having a product or service that guarantees the satisfaction of the final consumers.

\section{QUALITY MANAGEMENT MEASUREMENT SCALES}

In order to know where the company is located, authors a [5], mention that quality management represents an integrated and inter-functional mean to establish and keep a competitive advantage. Quality management practices can be divided in two groups: basic and environmental practices. In order to do the quality management basic practices, these authors describe the following five scales:

- Process control: this scale measures if companies do an statistic quality control to reduce variation in processes.

- Product design process: this scale evaluates if companies do a design effort among functions and simplify the designed product to improve the product s quality.

- Equipment and maintenance: this scale evaluates if companies make an effort to make their own equipment to satisfy specific needs and evaluates how the production plant carries out preventive maintenance. 
- Feedback; this scale measures if companies provide personnel with information on their performance (includes quality and productivity) in an opportune and useful manner. The scale measures the comments on performance both graphically and verbally, which are useful to facilitate and back up the quality and productivity of improvements.

These actions can be found in several companies concerned with a continuous improvement of their processes and are essential to measure the level of quality implemented in their processes, but they provide us with a question: are these actions in quality processes being carried out in government entities? We could think that yes, but since the competitiveness among city councils is not seen, some would opt not to implement them, however, the ones who do implement these actions would see an improvement in their daily activities. In government entities, the actions implemented by senior management, which in this case are the majors, governors or state secretaries who are directly involved with processes through their management director, should find several ways of using their data, because it can become a strong factor in improvement the mobility of their processes through innovative ideas aimed to satisfy the needs of final users.

In Brazil, [14] consider public administration as the set of entities that form the Estate, focused on the lending of public services and satisfying the needs of citizens and communities through quality services, promoting social participation and efficiency in the development of public activity. It is possible to see that in Latin-American countries there are certain similarities in the way of ruling and thus, it can be senses that people who live in these countries have similar needs. Governments, having a large amount of citizens who must receive a high-level service like a company, should apply quality methods.

In Sweden, government quality is defined by [10], as: "The traditions and institutions by which authority in a country is exerted. This includes the process through which governments are selected, monitored and replaced, the ability of the government to formulate and effectively implement solid policies, and the respect of the citizens and the Estate for the ruling institutions that economically and socially interact with them". (0p. cit, 2008).

For these authors, the quality policy results of the government have been the subject of a lot of research; however, many debates in this field are yet to be resolved due to the lack of empiric indicators, for example, the issue of general governance been good or democracy promoting economic growth. To measure this, they propose to measure the rule of law, the perception on corruption and effectiveness of government.

In our country we could opt to measure perception on corruption, rule of law and effectiveness of government to have a particular idea of the status of government entities and thus, apply the correct quality processes.

Therefore, the aim of study is: Describe the perception that workers have of the company, as well as of the end users who receive the APIVER service.

\section{METHODOLOGY}

This study it is a non-experimental design, of type descriptive and cross-sectional. A questionnaire (Annex 1) will be applied to a sample of 11 command staff in the port community who has a direct contact with quality processes and another questionnaire (Annex 2) will be applied to 15 final users: contractors, blue-collar employees, work superintendents or supervisors. The application of questionnaires was done by the persons in charge of this research and with help of staff. The questionnaire used has a Liker scale design; where 1 totally disagree to 5 totally agree. The questionnaire helps us to know the opinions of APIVER personnel regarding quality processes application.

\section{Procedures (phases)}

-Do a digital survey.

- Selection of people surveyed according to their profile.

- Send the link to access the digital survey.

-Data gathering. 


\section{¿CÓMO SE PERCIBE LA APLICACIÓN DE PROCESOS DE CALIDAD DE LA INGENIERÍA, EN LA ADMINISTRACIÓN PÚBLICA?}

\section{Information gathering techniques}

The techniques used in the research process for data gathering were: digital surveys using the platform Google Drive, which have time, email and answers of the surveyed.

\section{RESULT AND DISCUSSION}

\section{a.- About opinion of command staff, we obtained the follow result:}

In Annex 1, this survey was applied to 11 command staff from APIVER, 6 men and 5 women, of whom 54\% are between 31 and 40 years old, 27\% between 21 and 30 years old and the rest are older than 41 years old. Regarding their schooling level 54\% had attended college and 46\% had a Master s degree.

The questions posed on the survey are: how much do you agree or disagree about APIVER covering the needs of their client with the provided service? The population answered the following: they agreed on a $63.6 \%, 18.2 \%$ do not agree or disagree and $18.2 \%$ totally agree. For the next question: in general, how satisfied do you feel about working in APIVER? A $45.5 \%$ responded to be very satisfied, while a $45.5 \%$ is totally satisfied and $9.1 \%$ is moderately satisfied with working in APIVER; this represents a high level of satisfaction about working in this company.

Getting into this matter, the question: how much do you agree about APIVER considering new ideas to simplify their processes? A $54.4 \%$ answered that they agree, a $27.3 \%$ neither agrees or disagrees and a $18.2 \%$ totally agrees; in this question it is possible to see that most agree with APIVER taking into account the ideas of the command staff to simplify processes. For the next question, how much do you agree about quality strategies applied in APIVER being well perceived by the final users? $72.7 \%$ of staff replied that they agree and a $27.3 \%$ totally agrees, which represents a high level of perception on final users perceiving well the quality strategies.

For the next question to the command staff: do personnel under your command follow to the letter the quality processes in APIVER? A $72.7 \%$ replied they do, a $18.2 \%$ said maybe and a $9.1 \%$ replied they do not, meaning that most of the staff follows to the letter the quality processes in APIVER, being this optimal for the company.

To measure the complexity in the application of quality processes in APIVER, the command staff answered that it is little complex (45.5\%), for a $27.3 \%$ it is moderately complex, for a $18.2 \%$ it is very complex and for a $9.1 \%$ it is not complex, providing us with a diversity of views on the matter, since even though most of them answered that it is not complex, it seems there are other ideas which could be reinforced.

For the question, how important do you think the implementation of quality processes in APIVER is? A $54.4 \%$ replied that it is very important and a $45 \%$ that it is totally important, which ensures that the implementation of quality processes is fundamental to APIVER. To measure the level of knowledge about the quality processes operated in APIVER, the command staff answered that they are very aware (54.5\%), $27.3 \%$ are totally aware and $9.1 \%$ are little aware, so it is possible to understand that almost a quarter of the surveyed are not aware of the processes and therefore, we could implement training courses on quality matters.

To measure the knowledge about quality processes involved in the departments of each boss, the following answers where obtained: $45.5 \%$ says they are very aware, $45.5 \%$ are totally aware and $9.1 \%$ moderately aware, meaning that most of the surveyed are aware of the processes directly involved in their departments.

Finally, for the next question: how often is training about quality processes implemented in APIVER? $54.4 \%$ replied that training is given frequently, $27.3 \%$ said very frequently, $9.1 \%$ moderately frequently and $9.1 \%$ little frequently, meaning that there is a high perception on training courses being regularly implemented, thus it can continue to be the same way.

\section{b.- About opinion of final clients, we obtained the follow result:}

For Annex 2, 15 surveys were applied to final clients of APIVER, who are divided as $53.3 \%$ are men and $46.7 \%$ are women; their ages are between 21 and 30 years old (66.7\%), 31 to 40 years old (20\%), 41 to 50 years old $(6.7 \%)$ and over 51 years old (6.7\%). The level of schooling shows that $86.7 \%$ have concluded a Bachelor degree and $13.3 \%$ have a Master degree. 
For the first question, do you consider you know or are aware about the quality processes with which APIVER operates? $40 \%$ said they are little aware, $40 \%$ moderately aware, $13.3 \%$ totally aware and $6.7 \%$ very aware. It can be seen that there is a low level of knowledge about quality processes; because of this, we could reinforce this information with quality training courses or workshops, so final users have the basic knowledge about the benefits of quality processes implemented in APIVER.

In the next question: regarding the quality processes with which APIVER operates in the Port Area, what is your perception about the compliance with quality in their processes? $40 \%$ responded they have a moderate perception, $33.3 \%$ have a very good perception, $13.3 \%$ have little perception and $13.3 \%$ have an excellent perception.

This data analysis shows a medium perception for the compliance of quality in processes, which can be reinforced by the same workshops.

In the next question: in your opinion, what influence does quality processes have in APIVER in their activities lent inside the Port Area? Clients answered that it is very important (60\%), for a $33.3 \%$ it is totally important and $6.7 \%$ said it is moderately important, which reinforces the proposal of the two precious questions.

To measure the most important criteria for the development of the job inside APIVER, clients consider that better operational control of public work is the most important, followed by the work efficiency, reducing time and costs and work quality, leaving as less important the competitiveness among companies (see graphic 1).

Graphic 1. Work development in APIVER

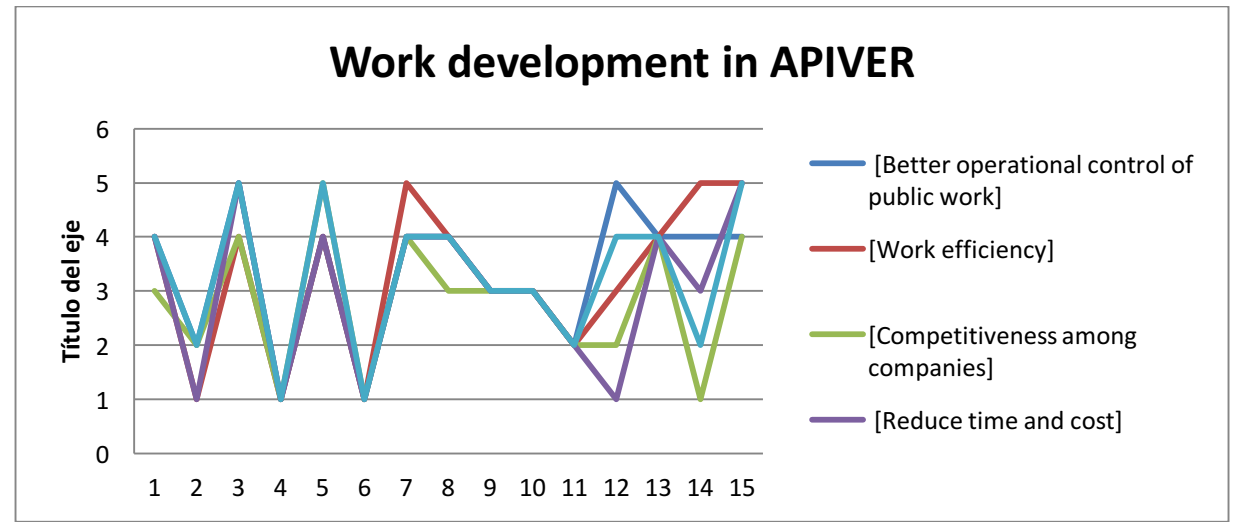

The question about how complex it is to apply the quality processes required by APIVER, got a diversity of responses, which are represented in a $46.7 \%$ as moderately complex, $20 \%$ very complex, $20 \%$ totally complex, $6.7 \%$ little complex and $6.7 \%$ not complex, which reinforces the proposal of implementing workshops to reinforce knowledge on the application of quality processes in APIVER, since more than $80 \%$ perceives said application as complex.

Finally, to measure the importance of the implementation of quality processes in APIVER, $66.7 \%$ of clients answered that it is very important and $33.3 \%$ said it is totally important, which represents the entirety of the surveyed who give a great importance to the implementation of quality processes in their daily life.

\section{CONCLUSION}

Having made this research about the application of quality processes in APIVER has proved that all the applied processes are unknown for many and basic for others, thus we can classify them in two groups: the first one is the APIVER personnel who applies and oversees the procedures, which should sound logic as this is qual- 


\section{¿CÓMO SE PERCIBE LA APLICACIÓN DE PROCESOS DE CALIDAD DE LA INGENIERÍA, EN LA ADMINISTRACIÓN PÚBLICA?}

ified personnel with basic knowledge of quality processes and the second group, personnel who collaborates externally in the port area and is indirectly involved in quality processes, this second group "should" have knowledge on the quality processes since their daily activities are directly involved with them; however, this could become an area of opportunity, several quality induction courses could be created and with them address this area of opportunity, closing the circle of knowledge so the first and second group could have a basic knowledge of quality processes in APIVER.

Through this research, it is recommended to make constantly monitor the personnel, so the organization has a clear idea of the people who have a basic knowledge of the processes, in this case the particular subject of "quality" should be even more watched and thus, get optimal performance in the company s processes.

\section{BIBLIOGRAPHIC REFERENCES}

Alzate-Ibañez, Angélica María, Ramírez Ríos, John Fredy, Bedoya Montoya, Laura María (2019), "Modelo para la implementación de un sistema integrado de gestión de calidad y ambiental en una empresa siderúrgica" Revista Ciencias Administrativas, Núm 7, № 13 enero-junio (2019), Pp. 4

Cantón Mayo, Isabel (2010), "Introducción a Ios procesos de calidad", Revista Iberoamericana sobre Calidad, Eficacia y Cambio en Educación, Núm. 5, Vol. 8, (2010).

Carro Paz, Roberto, González Gómez, Daniel (2015), "Administración de la calidad total", Universidad Nacional de Mar del Plata, Núm. 8, (2015). Pp. 11

Chiavenato Idalberto (2004); "Introducción a la Teoría General de la Administración”, Séptima Edición, de, McGraw-Hill Interamericana, 2004, Pp. 10.

Chi Anh, Phan, Matsui, Yoshiki (2006), "An empirical analysis of quality management practices in japanese manufacturing companies", Yokohama National University, International Graduate School of Social Sciences, June 14-18, 2006, pp. 126-137.

Contreras Orozco, Leticia (2010), "La calidad en la gestión como factor de cambio institucional en las organizaciones gubernamentales del Estado de México", Convergencia, UAEM, Núm. 53, mayo- agosto (2010). Pp. $285-310$

Domínguez Fernández, Guillermo, Lozano Pérez, Luz (2005), "La calidad, más que una moda, un reto en la Europa de la Sociedad del Conocimiento: la mejora continua más allá de los modelos y las certificaciones (competencias de un formador que aseguran la calidad)", Revista Complutense de Educación, Vol. 16 Núm. 1 (2005)

García P, Manuel; Quispe A., Carlos; Ráez G., Luis (2003), "Mejora continua de la calidad en los procesos", Industrial Data, vol. 6, Núm. 1, agosto, (2003) Pp. 89-94

García-Santillán, A. (2010) Administración Financiera I, Edición electrónica. Universidad de Málaga ISBN-13: 978-84-693-7162-6 Registro en la Biblioteca Nacional de España № 10/101867. Recuperado de: http://www.eumed.net/libros-gratis/2010c/729/index.htm

Holmberg, Sören, Rothstein, Bo, Nasiritousi, Naghmeh (2008), "Quality of Government: What You Get", The Quality of Gobernment Institute ISSN 1653-8919, September (2008) Pp. 1-34

López Gumucio, Ricardo (2005), "La calidad total en la empresa moderna", Perspectivas, Vol. 8 Núm, 2, (2005), Pp. 67-87

Löffler Elke (2013), "Defining Quality in Public Administration", Quality in Public Administration: Basic Concepts and Comparative Perspective, Mayo, 10, (2013).

Marín Portillo, Kattiuska, Atencio Cárdenas, Edith (2008), "Proceso Académico-Administrativo de la Revista Científica y Ética del Investigador: estudio de un caso", Omnia, Vol. 14, Núm. 3 (2008) P.p. 160-183

Melati, Claudia, Janissek-Muniz, Raquel, Curacao, Carla (2018), "Quality in public administration: A causal configuration analysis", Refereed Paper Proceedings - KM Conference 2018, (2018).

Mohammed Abu, Zayed (1994), "Total Quality Management: the Case for the Public Sector: a Comparative Study of the Implementation of Total Quality Management in Three Health Care Organizations", Portland State University, Pp. 17 and 304. 
Neyestani, Behnam (2017), "Principles and Contributions of Total Quality Mangement (TQM) Gurus on Business Quality Improvement", Publication of the International Institute for Applied Knowledge Management, De La Salle University, Manila, Philippines, February, (2017) Pp. 3

Uvalle Berrones, Ricardo (2009), "Condiciones, procesos y tendencias de la administración pública contemporánea", CONVERGENCIA Revista de Ciencias Sociales, Núm. 49, 2009

Valdés Huezo, Josué Cirino (2015), "El Instituto Federal de Telecomunicaciones. Un ejemplo de autonomía eficaz", INAP Revista de Administración Pública, Núm. 138, Vol. L, 2015.

Vásquez Rodríguez, Jorge Alberto (2016), "El manual maestro de procesos y procedimientos, un paso hacia la gestión de calidad: el caso del consejo nacional de vialidad", Revista Nacional de Administración, 7 (2), 2016.

Vicher-García, Mónica Diana (2012), "Utilidad o futilidad: calidad e ISOs en la administración pública", CONVERGENCIA Revista de Ciencias Sociales, Núm. 60, (2012).

Wynen Jan, Verhoest Koen (2015), "Quality Management in Public Sector Organizations: Evidence from Six EU Countries", International Journal of Public Administration, July 2015.

\section{Consulted websites}

International Organization for Standardization, All About ISO, march 12, 2019. Retrieved of: https://www.iso.org/home.htm/

Instituto Federal de Telecomuniaciones, Filosofía, march 13, 2019. Retrieved of: http://www.ift.org.mx/conocenos/filosofia

API Veracruz, Historia, marzo 14, 2019. Retrieved of: https://www.puertodeveracruz.com.mx/wordpress/quienessomos/historia/ 
¿CÓMO SE PERCIBE LA APLICACIÓN DE PROCESOS DE CALIDAD DE LA INGENIERÍA,

EN LA ADMINISTRACIÓN PÚBLICA?

\section{Annex 1}

Questionnaire for command staff of APIVER

General information of the surveyed

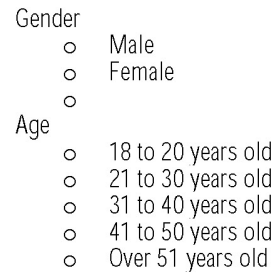

Last grade of schooling
- Elementary
Junior high
High-school
College
Graduate
- PhD

General

1.- In your opinion, how much do you agree or disagree about APIVER covering the needs of their client with the provided service?

- Totally agree

- Agree

- Neither aqree nor disaqree

- Disagree

- Totally disagree

2.- In general, How satisfied do you feel about working in APIVER?
- Totally satisfied
- Very satisfied
- Moderately satisfied
- Little satisfied
- Not satisfied

Quality processes

3.- How much do you agree about APIVER considering new ideas to simplify their processes?
- Totally agree
- Agree
- Neither agree nor disagree
- Disagree
- Totally disagree

4.- How much do you agree about quality strategies applied in APIVER being well perceived by their final users?
- Totally agree
- Agree
Neither agree nor disagree
- Disagree
- Totally disagree

5.- Do personnel under your command follow to the letter APIVER's quality processes?
- Yes
- No
- Maybe 
6.- How complex it is to apply quality processes in APIVER?

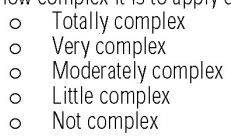

7.- How important do you think the implementation of quality processes in APIVER is?

- Totally important

- Very important

- Moderately important

- Little important

- Not important

\section{Knowledge}

8.- In your opinion, do you consider to be fully aware and know all about the quality process with which APIVER operates?
- Totally aware
- Very aware
- Moderately aware
- Little aware
- Not aware

9.- Regarding the quality processes in your area, how much do you know about the quality processes in which your area is involved?
- Totally aware
- Very aware
- Moderately aware
- Little aware
- Not aware

10.- In your opinion, how often is training about quality processes implemented in APIVER?
- Very frequently
- Frequently
- Moderately frequently
- Little frequently
- Training is not implemented

\section{Annex 2}

Questionnaire for final users

General information of the surveyed

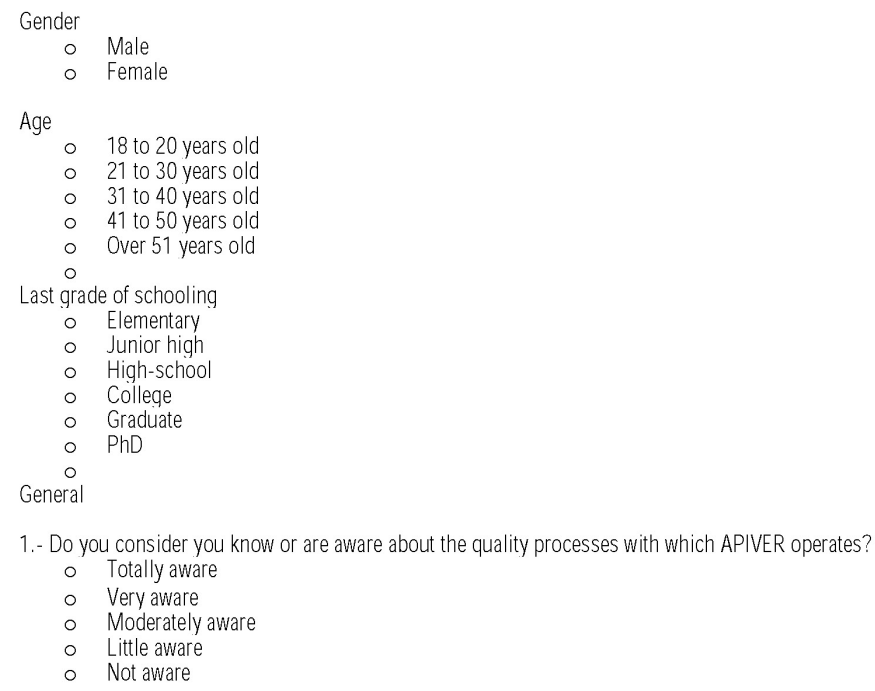

1.- Do you consider you know or are aware about the quality processes with which APIVER operates?
- Totally aware
- Very aware
- Moderately aware
- Little aware
- Not aware 


\section{¿CÓMO SE PERCIBE LA APLICACIÓN DE PROCESOS DE CALIDAD DE LA INGENIERÍA,}

EN LA ADMINISTRACIÓN PÚBLICA?

2.- Reqarding the quality processes with which APIVER operates in the Port Area, what is your perception about the compliance of quality in their processes?

- Excellent perception

- Very good perception

- Moderate perception

- Little perception

- No perception

3.- In your opinion, what influence do quality processes have in APIVER, in their activities lent inside the Port Area?

- Totally important

- Very important

- Moderately important

- Little important

- Not important

4.- In your responsibilities in the Port Area, what is the criteria you consider to be the most important for the performance of your job? Please enumerate in importance order from 1 to 5 , where 5 is the most important and 1 the least important.

- Better operational control of public work

- Work efficiency

Competitiveness among companies

- Reduce time and costs

- Work quality

5.- In your opinion, how complex it is to apply the quality processes required by APIVER?
- Totally complex
Very complex
Moderately complex
Little complex
- Not complex

6.- Finally, in your opinion how important do you think the implementation of quality processes in APIVER is?

- Totally important

- Very important

- Moderately important

- Little important

- Not important 